\title{
IMPACT OF GREEN MANAGEMENT ON CEO COMPENSATION: INTERPLAY OF THE AGENCY THEORY AND INSTITUTIONAL THEORY PERSPECTIVES
}

\author{
A. Banu Goktan \\ Division of Business and Public Leadership, University of North Texas at Dallas, \\ 7300 University Hills Blvd., Dallas, 75241 Texas, USA \\ E-mail:banu.goktan@unt.edu
}

Received 25 August 2011; accepted 09 July 2012

\begin{abstract}
There has been growing interest in green management practices among practitioners, researchers and regulators in recent years. However, there is limited research that examines the connection between natural environments and human resource management practices. The current study examined the relationship between Chief Executive Officer (CEO) compensation and green management practices within the agency theory and institutional theory frameworks. Results revealed a significant negative relationship between green management practices and CEO base pay, however, there was not a significant relationship between green management practices and CEO bonuses. In line with previous agency theory research, findings suggest a negative relationship between state regulation and CEO compensation in green states. An important implication for practice is that the negative relationship may strengthen negative perceptions about green management practices among CEOs and reduce willingness to implement green management practices.
\end{abstract}

Keywords: green management, CEO pay, executive compensation, agency theory, institutional theory, isomorphism.

Reference to this paper should be made as follows: Goktan, A. B. 2014. Impact of green management on CEO compensation: interplay of the agency theory and institutional theory perspectives, Journal of Business Economics and Management 15(1): 96-110.

JEL Classification: M12, M52, Q56, K23, K32.

\section{Introduction}

Today, "we live in an era of sustainability awareness" (Starik, Marcus 2000: 539) and there is growing pressure on organizations to adopt green practices. Environmental sustainability has become a strategic issue for organizations and the topic has generated concerns among business executives, governments, consumers, and management scholars (Delmas, Toffel 2008; Gallarotti 1995; Orsato 2006; Rehman, Shrivastava 2011; Zee et al. 2011). This trend is due to the growing environmental and social movement and the perception that organizations have or could have significant impact on their respective ecosystems (Starik, Marcus 2000). With the growing pressures from the federal and local governments, society, consumers and competitors (Jackson et al. 2011), organiza- 
tions are pressured to devote more of their resources to environmentally and socially responsible endeavors.

Despite the growing emphasis on green management practices, the examination of the connection between natural environments and organizations is a relatively recent scholarly phenomenon (Renwick et al. 2008; Starik, Marcus 2000). As various stakeholders have been struggling with the challenges and opportunities presented by environmental issues, "Human resource management (HRM) scholars and practitioners alike have been relatively slow to engage in the ongoing discussions and debates" and research that examines the relationship between HRM and environmental management is scarce (Jackson et al. 2011). Although CEO (Chief Executive Officer) compensation is one of the most widely examined HRM topics (Gomez-Mejia, Balkin 1992; Tosi et al. 2000), we do not know enough about the relationship between green management practices and CEO compensation (Lothe, Myrtveit 2003; Renwick et al. 2008). There are only a few studies that have examined this relationship (e.g. Berrone, Gomez-Meja 2009; Cordeiro, Sarkis 2008; Gallarotti 1995; P. A. Stanwick, S. D. Stanwick 2001).

The fascination with CEO compensation is not recent. Articles on the topic of CEO compensation date back as far as 1925. Interest in the connection between CEO compensation and green management issues has increased in recent years (Cordeiro, Sarkis 2008; Essen et al. 2012; Moriarty 2009; O’Reilly III, Main 2007; Renwick et al. 2008). Compensation systems affect the CEOs' perceptions about and efforts towards green management practices (Lothe, Myrtveit 2003). These perceptions, motivations and decisions, in return, have a significant impact on managerial decision and on the environment (Cordeiro, Sarkis 2008). Therefore, examining the link between green management practices and CEO compensation is of interest to both organizations and society.

In this study, the relationship between green management practices and CEO compensation is examined by expanding on agency theory and including insights from institutional theory. It is argued that laws and regulations, which is the most widely cited driver of green management practices (e.g. Barry et al. 1993; Rojšek 2001; Y. Yen, S. Yen 2012), create isomorphic pressures on organizations at the state level and affect the agent-principal relationship. It is proposed, based on agency theory that increased regulation will limit the discretion of the CEO and, therefore, have a negative effect on CEO compensation.

\section{Theoretical background}

The compensation system of an organization is partly determined by the environment in which it operates (Chu et al. 2006; Lawler 1987; Milkovich 1988). Among environmental factors discussed in literature in relation to pay are labor unions, regulatory changes, and product and labor market pressures. Geographic variables such as location have also been significantly related to compensation (Krueger, Summers 1988). Institutional theory, as a theory that explains the effect of external environmental pressures on organizations, received little attention from researchers in the field of human resource management (e.g. Berrone, Gomez-Meja 2009). In the following sections, institutional 
theory will be discussed as it relates to green management practices and the agentprincipal relationship. It is argued that in states where isomorphic pressures to implement green management practices exist, CEO pay is lower due to the limited decision making power of the CEOs as suggested by agency theory.

\subsection{Institutional theory}

Traditionally, institutional theory described how isomorphic institutional pressures lead to common organizational practices (DiMaggio, Powell 1983). Isomorphism can be defined as pressures from social institutions to follow similar paths in management practices (DiMaggio, Powell 1983; Powell, DiMaggio 1991). There are three different forms of isomorphism including coercive, mimetic and normative isomorphism. Coercive isomorphism results from the coercive forces from social institutions in the organization's environment to adopt certain practices (Zucker 1987). Mimetic pressure, on the other hand, results from the organization's motivation to imitate the behavior of other organizations in their institutional fields (Delmas, Toffel 2008). In a way, organizations try to copy and implement best practices or beneficial structures that they see in other organizations. The third source of isomorphic pressure is normative which results from pressures from the professional field. Formal education and the cognitive base produced in educational institutions as well as the growth and influence of professional networks allow new practices to be diffused across organizations (DiMaggio, Powell 1983).

A review of the limited research in the field of green management practices reveals that these different types of isomorphic pressures (i.e. coercive, normative and mimetic) discussed above have different sources and consequences. Coercive or normative pressures come from institutional agents, such as the state, local community, interest groups and professional bodies, whereas mimetic influences stem from similar or related organizations (DiMaggio, Powell 1983). For example, in businesses fields where green management practices bring economic returns, there will be mimetic pressures on organizations to implement similar practices and they will voluntarily adopt green management practices (Starik, Marcus 2000; Zucker 1987). To the contrary, regulations pertaining to environmental policies coerce organizations to adopt green management practices (i.e. coercive isomorphism). "Since the 1960s, organizations have found themselves under increasing institutional pressure to attend to

environmental sustainability as part of their corporate agenda" (Walls, Hoffman 2012: 1). While regulatory pressures, market competitive pressures and customer pressures have been identified as the main drivers of green management (Rehman, Shrivastava 2011), regulatory pressures is the most widely cited driver of green management (Barry et al. 1993; Livingstone, Sparks 1994; Murphy et al. 1995; Pohlen, Farris 1992; Rojšek 2001; Winsemius, Guntram 1992; BearingPoint ... 2008; Y. Yen, S. Yen 2012; Lai, Wong 2012; Bose, Pal 2012; De Giovanni 2012; Green et al. 1996; Nawrocka 2008). Many organizations respond to institutional pressures by adhering to accepted and legitimated environmental standards (Walls, Hoffman 2012). According to Kulwiec (2002) there are hundreds of laws and regulations within individual states making regulatory pressures the most important driver among all. Although many organizations have start- 
ed responding to environmental issues proactively and viewing environmental issues as a part of the organization's strategy in recent years (Gallarotti 1995; Walls et al. 2012; Walls, Hoffman 2012), for many organizations the objective of implementing green management practices is still to avoid sanctions associated with failing to meet government rules or regulations (Delmas, Toffel 2004, 2008).

Jennings and Zandbergen (1995) were amongst the first to apply institutional theory to explain firms' adoption of environmental management practices. They argue that coercive forces, primarily in the form of regulatory enforcement, have been the main motivators for organizations to adopt environmental management practices. Federal and local governments impose coercive pressure on organizations to implement similar practices through regulatory enforcement and companies adopt green management practices to avoid sanctions (Delmas, Toffel 2004; Gallarotti 1995). Several studies found that company decisions to adopt environmental management practices were influenced by the desire to improve or maintain relations with their communities (Delmas, Toffel 2004, 2008). Not surprisingly many green management initiatives have been at the state level (see Bose, Pal 2012; Clean Energy States Alliance 2004; Kulwiec 2002; Rogers, Trüb 2008; Wingfield, Marcus 2007) and they have resulted from coercive and normative pressures from local governments and NGOs. In addition to federal laws regarding green management practices, states have their own rules and regulations. Similarly, local professional organizations help increase awareness about environmental issues and shape norms in their respective fields, set certain standards and in a way pressure organizations to implement green management practices though normative isomorphism (Zucker 1987).

Organizations located in the same state are exposed to the same rules and regulations (i.e. coercive pressures) and affected by the norms of NGOs (ex. Clean Energy States Alliance 2004) to adopt similar green management practices. Since the activities of NGOs and regulations differ from state to state, some states are greener than others (Rogers, Trüb 2008; Wingfield, Marcus 2007). In sum, institutional pressures are stronger in some states than others which results in similar practices within the state but dissimilar practices across states (Delmas, Toffel 2008).

\subsection{Agency theory}

Most research on CEO pay has an agency-theoretic orientation (Balkin et al. 2000; Cordeiro, Sarkis 2008). Agency theory explains the relationship between the principal and the agent in which one party (principal/owner) delegates work to another (agent/ manager). Agency problem arises when the interests and goals of the agents and principals are in conflict. These conflicts may be over the amount of effort to be exerted, risk to be borne, or strategic choices (Cordeiro, Sarkis 2008; Davis 2005; Shapiro 2005). Agency cost refers to the cost of resolving conflicts between the principals and agents and aligning interests of the two groups (Eisenhardt 1989). Compensation contracts are designed to align CEO's financial interests with the company interests to reduce agency related problems (Arya, Sun 2004; Chu et al. 2006). 
Several previous studies have focused on the effect of regulation on CEO compensation within the agency framework. Research to date suggests that there is a significant negative relationship between regulation and CEO compensation (Lin, $\mathrm{Su} 2009$ ). Crawford, Ezzell and Miles (1995) showed a relationship between CEO's compensation and regulatory changes in the banking industry in the early 1980s. Hubbard and Palia (1995) found higher levels of CEO pay for banks operating in more competitive environments. Kole and Lehn (1999) found a significant relationship between deregulation in the airline industry and CEO compensation. Bryan et al. (2005) showed a significant relationship between CEO compensation and deregulation in the electric-utility industry. Similarly, Arya and Sun (2004) found that annual CEO compensation increased following the 1992 Energy Policy Act and the deregulation of the electric and utilities industry.

The negative relationship between regulation in the industry and CEO compensation may be partly due to information asymmetry. Usually principle is unsure whether the agent has performed the work or whether he/she engaged in opportunistic behavior. Information asymmetry reduces the principal's ability to control actions of the agent (Arnold, Lange 2004). The greater the discretion of the agent, the greater the potential for opportunistic behavior. From an agency theory perspective, CEO compensation is higher in competitive environments because the greater freedom in the environment provides greater discretion to the agent (CEO) in decision making. Therefore, the potential for the decisions to be in conflict with the interests of the principals (shareholders) increases. Although literature on executive compensation suggests that interests may be aligned and agency costs may be reduced by tying the manager's compensation directly to firm performance or firm value, there is no concrete theoretical or empirical consensus on the impact of different forms of compensation on managerial decisions (Core et al. 2003; Murphy 1999). In many organizations, principals choose to pay the CEO's high levels of compensation so that they work in the best interest of the organization. The greater the pay, the greater the potential loss faced by the CEO (Shapiro 2005). On the other hand, regulations set limitations to the scope of the CEO's job, reduce the manager's investment discretion, increase monitoring and political pressure (Bryan et al. 2000; Joskow et al. 1996; Smith, Watts 1992).

Coercive and normative pressures imposed on organizations towards the implementation of green practices increase regulation in firms (Gallarotti 1995; P. A. Stanwick, S. D. Stanwick 2001) and restrict decision making freedom of CEOs. The decisionmaking power of CEOs will be limited by rules of green management practices and the chances that the decisions of the agent (CEO) will be in conflict with the interests of the principal (shareholder) will be lower. Lower discretion in decision making will be accompanied by lower CEO pay. Therefore, CEOs compensation will be lower in green states.

H1: There is a negative relationship between green management practices and CEO pay levels. CEO base pay will be lower in green states.

Earlier studies on regulation and CEO compensation have documented that regulated firms are less likely to use incentive-based compensation, such as bonuses and stock options, than unregulated firms (e.g., Bryan et al. 2000; J. J. Gaver, K. M. Gaver 1993). 
Increased constraints discussed above reduce the need to pay management bonuses, stock options and other incentive-based compensation in addition to a base salary (Bryan et al. 2000). CEO's of firms in unregulated industries have more discretion in decision making and, therefore, they have more power to effect company performance and shareholder wealth. In order to align the interests of the principal (shareholders) and the agent (CEO) and to make sure CEOs work towards the achievement of high organizational performance, $\mathrm{CEO}$ bonuses needs to be tied to organizational performance in unregulated firms (Arya, Sun 2004; Joskow et al. 1996). The objective of bonuses or stock options is to provide incentives to the CEO to make shareholder wealth maximizing decision. Regulated firms, on the other hand, will rely less on incentive based compensation such as bonuses, than unregulated firms because regulations will limit the scope of the CEO's job (Arya, Sun 2004; Joskow et al. 1996). Therefore:

H2: There is a negative relationship between green management practices and CEO bonuses. CEO bonuses will be lower in green states.

\section{Data and methods}

Data was collected from the Hoover's (2008) database. Only companies in the United States that had 100 or more employees were included in the study. Companies with less than 100 employees are considered small companies (Cullen 2002). They were excluded from the study because they may not have the resources necessary to implement green management practices (Gallarotti 1995). Also, low-wage and high-wage industries were selected based on lietarature prior to data collection to make sure both groups were represented in the sample (Erdil, Yetkiner 2001; Krueger, Summers 1988; Neal 1993; Thaler 1989; Wolfson, Belman 2004). Industries included in the study are the following: semiconductor, energy and utilities, telecommunication equipment, chemicals, computer software, metals and mining, apparel retail, telecommunication services, consumer services, restaurant, and agriculture industries. Companies that were listed in the Hoover's database in the selected industries which had 100 or more employees and which had CEO pay and bonus records available were included in the data. None of the states in the United States were excluded from the study. Table 1 shows the distribution of companies based on industry and green management practices.

\subsection{Measures}

To ensure internal validity, a study must be designed in such a way that rival hypotheses are ruled out and spurious covariance among study variables are minimized or removed. Based on a review of compensation literature, company age and size, measured in terms of company sales, were included as a control variables in the analyses (Berrone, GomezMejia 2009; Cordeiro, Sarkis 2008).

The green states were identified based on Forbes listing of green states (Wingfield, Marcus 2007) and 2008 Business Facilities Rankings Report (Rogers, Trüb 2008). These states were also members of the Clean Energy States Alliance. Only the states included in the top 15 of the two lists were included as green states in this study. The rankings 
Table 1. Distribution of companies included in the study based on industry and green management practices

\begin{tabular}{lcccc}
\hline & $\begin{array}{c}\text { No of } \\
\text { companies } \\
\mathrm{N}=674\end{array}$ & $\begin{array}{c}\text { Percent } \\
\text { of companies } \\
\mathrm{N}=674\end{array}$ & $\begin{array}{c}\text { No of companies } \\
\text { in green states } \\
\mathrm{N}=309\end{array}$ & $\begin{array}{c}\text { Percentage } \\
\text { of companies } \\
\text { in green states }\end{array}$ \\
\hline Agriculture & 9 & 1.3 & 1 & $11 \%$ \\
\hline Chemicals & 71 & 10.5 & 26 & $37 \%$ \\
\hline Computer software & 65 & 9.6 & 42 & $65 \%$ \\
\hline Consumer services & 27 & 4.0 & 10 & $37 \%$ \\
\hline $\begin{array}{l}\text { Electronics - } \\
\text { semiconductor }\end{array}$ & 207 & 30.7 & 129 & $62 \%$ \\
\hline Energy and utilities & 41 & 6.1 & 7 & $30 \%$ \\
\hline Leisure - restaurants & 47 & 7.0 & 14 & $15 \%$ \\
\hline Metals and mining & 47 & 7.0 & 7 & $50 \%$ \\
\hline Retail - apparel & 42 & 6.2 & 21 & $55 \%$ \\
\hline $\begin{array}{l}\text { Telecommunication } \\
\text { equipment }\end{array}$ & 49 & 7.3 & 27 & $36 \%$ \\
\hline $\begin{array}{l}\text { Telecommunication } \\
\text { services }\end{array}$ & 69 & 10.2 & 25 & \\
\hline
\end{tabular}

Table 2. Criteria used in determining green states

Categories, listed in order of weight, used to formulate the Top 10 Greenest States in the Business Facilities Rankings Report 2008 (Rogers, Trüb 2008)

Total Pollution Released by Pounds of Toxins

Financial incentives for Energy Efficiency

Financial Incentives for Renewable Energy

Rules, Regulations, and Policies for Renewable Energy

Rules, Regulations, and Policies for Energy Efficiency

Number of LEED-certified Buildings

Number of Hazardous Waste Sites by State

Total Air Emissions

Percentage of People who Use Public Transportation

Equally weighted categories used to formulate America's Greenest States by Forbes Magazine (Wingfield, Marcus 2007).

Carbon footprint

Air quality

Water quality

Hazardous waste management

Policy initiatives

Energy consumption 
mainly relied on the states' policies regarding renewable energy and waste management and focus on efficiency and environmental policy initiatives (See Table 2). The green states included in the study based on these rankings are California, Connecticut, Massachusetts, Minnesota, New Jersey, New York, Oregon, and Wisconsin. The nongreen states include Arkansas, Alabama, Arizona, Colorado, Delaware, Florida, Georgia, Hawaii, Iowa, Idaho, Illinois, Indiana, Kansas, Kentucky, Louisiana, Missouri, Massachusetts, Utah, North Carolina, Ohio, Oklahoma, Pennsylvania, Tennessee, Texas, and Washington. $46 \%$ of companies were located or headquartered in green states and $54 \%$ in non-green states (See Table 1).

CEO base pay and bonus pay, the dependt variable data, was obtained from the Hoover's (2008) database.

The primary statistical techniques used to analyze data in this study included descriptive statistics, bivariate correlations (Pearson product moment correlations) (Table 3), and multivariate hierarchical regression (Tables 4 and 5).

Table 3. Descriptive statistics and correlations $(\mathrm{N}=673)$

\begin{tabular}{lcccccccc}
\hline & Mean & St. Deviation & 1 & 2 & 3 & 4 & 5 & 6 \\
\hline $\begin{array}{l}\text { Public-Private (1) } \\
\text { Public 1, Private 0 }\end{array}$ & .96 & .19 & 1 & & & & \\
\hline $\begin{array}{l}\text { Green-Non Green } \\
\text { States (2) }\end{array}$ & .46 & .50 & -.03 & 1 & & & & \\
Green 1, Non Green 0 & & & & & & & & \\
\hline Company Sales (3) & 3122.39 & 10843.50 & .03 & -.03 & 1 & & \\
\hline Company Age (4) & 32.49 & 31.66 & $.12^{* *}$ & $-.13^{* *}$ & $.26^{* *}$ & 1 & & \\
\hline Salary (5) & 547468.84 & 480714.70 & .01 & $-.10^{*}$ & $.33^{* *}$ & $.21^{* *}$ & 1 & \\
\hline Bonus (6) & 376043.77 & 1017969.94 & .01 & -.04 & $.29^{* *}$ & $.13^{* *}$ & $.23^{* *}$ & 1 \\
\hline
\end{tabular}

Notes: ** Correlation is significant at the 0.01 level (2-tailed); ${ }^{*}$ Correlation is significant at the 0.05 level (2-tailed).

\section{Results}

Most of the intercorrelations among the variables in this study were in line with expectations (see Table 4). There was a significant correlation between salary, company age, company sales and green states as expected. CEO bonus was significantly correlated with company sales and company age but not with green states. Whether the company was public or private was not significantly related to CEO salary or bonus. While bivariate correlations may provide some evidence for main effects, they might be misleading when independent variables are correlated (Greve 2003). Therefore, hierarchical multivariate regression was used when testing hypotheses.

Tables 4 and 5 report the results of hierarchical multivariate regression analyses for both CEO base pay and bonus. In order to understand the effect of each independent variable, control variables were entered first and independent variable was entered next. Model 
1 in each table presents the regression results of the control variables on the dependent variable. By looking at the following models, we can see how the explanatory power of the model changes according to each independent variable added.

Hypothesis 1 proposes a negative relationhsip between green management practices and CEO base pay whereas hypothesis 2 proposes a negative relationship between green management practices and CEO bonuses. According to Model 2 in Table 4, CEO base pay is lower in greener states and the relationsip is significant $(p<0.05)$ supporting hypothesis 1 . Model 2 in Table 5 reveals no significant relationship between green management practices and CEO bonuses although the relationship is in the expected direction. Therefore, hypothesis 2 is not supported.

Table 4. Results of the regression analysis for CEO base pay $(\mathrm{N}=659)$

\begin{tabular}{lcc}
\hline \multicolumn{1}{c}{ Variables } & Model 1 (Controls only) & Model 2 (H2) \\
\hline Company Sales & $.30^{* * *}$ & $.30^{* * *}$ \\
\hline Company Age & $.13^{* * *}$ & $.12^{* * *}$ \\
\hline Public/Private & -.02 & -.02 \\
\hline Green Management & Independent Variable & $-.08^{*}$ \\
\hline Constant & $491010.80^{* * *}$ & $535951.58^{* * *}$ \\
\hline $\mathrm{F}$ & $32.68^{* * *}$ & $25.80^{* * *}$ \\
\hline $\mathrm{R}^{2}$ & .13 & .14 \\
\hline
\end{tabular}

Notes: Standardized coefficients are shown. Significance levels: $* p<.05 .{ }^{* *} p<.01 * * * p<.001$.

Table 5. Results of the regression analysis for CEO bonus $(\mathrm{N}=658)$

\begin{tabular}{lcc}
\hline \multicolumn{1}{c}{ Variables } & Model 1 (Controls only) & Model 2 (H2) \\
\hline Company Sales & $.27^{* * *}$ & $.27^{* * *}$ \\
\hline Company Age & .06 & .05 \\
\hline Public/Private & -.01 & -.01 \\
\hline
\end{tabular}

Independent Variable

\begin{tabular}{lcc}
\hline Green Management & -.02 \\
\hline Constant & 289808.15 & 318856.27 \\
\hline $\mathrm{F}$ & 20.55 & 15.50 \\
\hline $\mathrm{R}^{2}$ & $.09 * * *$ & .09 \\
\hline
\end{tabular}

Notes: Standardized coefficients are shown. Significance levels: $* p<.05 . * * p<.01 * * * p<.001$. 


\section{Conclusions and discussions}

Green management and CEO compensation are two fields of study that have received considerable attention in the last few years. Although we live in an era of sustainability awareness as stated by Starik and Marcus (2000), we do not know much about how green management initiatives impact human resource management practices in general and CEO compensation in particular (Jackson et al. 2011). Gallarotti published the article titled "It pays to be green" in 1995 and drew attention to the link between managerial incentive structure and environmentally sound strategies. While environmental studies have proliferated in recent years, studies examining the link between CEO pay and green management practices are limited (e.g. Berrone, Gomez-Mejia 2009).

This study contributes to research in the field by expanding on agency theory and including insights from institutional theory as suggested by Eisenhardt (1989) and Berrone and Gomez-Meja (2009). Studies to date suggest that isomorphic pressures at the state level affect the adoption of green management practices by organizations (Kulwiec 2002; Delmas, Toffel 2004, 2008); however few empirical studies have examined green management practices within the institutional theory framework. Another contribution of this study is the examination of the link between natural environments and human resource management practices. Results show that there is a significant relationship between CEO pay and green management practices. Results suggest that CEO base bay is lower in states where isomorphic pressures to implement green management practices are higher.

The negative relationship between green management practices and CEO compensation in the current study is in line with previous studies, for example studies examining the effect of deregulation in the electric industry and CEO compensation (e.g. Arya, Sun 2004; Bryan et al. 2005). Studies to date show a negative relationship between regulation and CEO compensation. However, in this study regulation was negatively related to CEO base pay but not to bonuses. Future studies should include voluntary versus mandatory implementation of green management practices as a control variable. It is possible that when organizations voluntarily implement green management practices and turn them into competitive advantage, such as greater customer demand or greater operational efficiency, firm profitability increases which in turn reflects on CEO bonuses. Future studies should also include company performance, such as firm profitability, as a control variable in the analysis since bonuses are mostly tied to company performance (Essen et al. 2012).

Contrary to our expectations, CEO bonus was not lower in green states.

These results have important implications because CEOs will not be motivated to implement green management practices unless there is a positive relationship between green management practices and CEO compensation (i.e. base pay and bonus). From an agency theory perspective, unless the interests of the $\mathrm{CEO}$ are aligned with company results, there is potential for opportunistic behavior. CEO may choose decisions that are in line with their own personal interest. Furthermore, the negative relationship between green management practices and CEO base pay that the results revealed may strengthen 
negative perceptions about green management practices. CEOs have decision making power on issues that affect the survival and success of organizations as well as the society as a whole. The lack of incentives provided to CEOs may hinder green management practice adoption and implementation by firms due to the negative perceptions of CEOs.

This study offers an alternative by examining environmental management practices from an institutional theory perspective. Majority of the studies in the field of environmental management used ISO 14001 adoption and pollution indices such as U.S. EPA's toxic release inventory (e.g. Berrone, Gomez-Mejia 2009; Delmas, Toffel 2008; King, Lenox 2002; Sharma 2000) as measures of environmental management. The EPA inventory consists of firms only from industries that are subject to reporting under the EPA's program which requires facilities exceeding a threshold level to report their emissions (Berrone, Gomez-Mejia 2009). This study has a broader focus and includes multiple industries. Considering that the service sector rather than the manufacturing sector dominates the Unites States economy, it is important to understand CEO compensation in a wide range of industries.

From that perspective, the high representation of the semi-conductor industry in the sample is both strength and a weakness of the current study. While it is important to understand CEO compensation in the service sector, our sample is not representative of all industries. Even though the sample was balanced in terms of percentage of companies in green versus non-green states, future studies should work with a more balanced represenation of industries in the sample. Also, this study can be replicated applying the questionnaire method and directly contacting organizations to learn about their green management practices.

\section{References}

Arnold, B.; Lange, P. 2004. Enron: an examination of agency problems, Critical Perspectives on Accounting 15: 751-765. http://dx.doi.org/10.1016/j.cpa.2003.08.005

Arya, A; Sun, H. L. 2004. Impact of deregulation on CEO compensation: the case of electric utilities, American Business Review 22(1): 27-33.

Balkin, D. B.; Markman, G. D.; Gomez-Mejia, L. R. 2000. Is CEO pay in high-technology firms related to innovation?, Academy of Management Journal 43(6): 1118-1129.

http://dx.doi.org/10.2307/1556340

Barry, J.; Girard, G.; Perras, C. 1993. Logistics planning shifts into reverse, The Journal of European Business 5(1): 34-7.

BearingPoint Supply Chain Magazine 2008. How mature is the green supply chain? [online], [cited 6 November 2013]. Available from Internet: http://supplychainstandardadmin.madgex.com/ assets/getAsset.aspx?liAssetID=530

Berrone, P.; Gomez-Mejia, L. R. 2009. Environmental performance and executive compensation: an integrated agency-institutional perspective, Academy of Management Journal 52(1): 103-126. http://dx.doi.org/10.5465/AMJ.2009.36461950

Bose, I.; Pal, R. 2012. Do green supply chain management initiatives impact stock prices of firms?, Decision Support Systems 52: 624-634. http://dx.doi.org/10.1016/j.dss.2011.10.020

Bryan, S.; Hwang, L.; Lilien, S. 2000. CEO stock-based compensation: an empirical analysis of incentive-intensity, relative mix, and economic determinants, Journal of Business 73: 661-93. http://dx.doi.org/10.1086/209658 
Bryan, S.; Hwang, L. S.; Lilien, S. 2005. CEO compensation after deregulation: the case of electric utilities, Journal of Business 78(5): 1709-1752. http://dx.doi.org/10.1086/431440

Chu, C. M.; Hu, H. H.; Chu, N. T. 2006. A framework for interpreting the antecedents of CEO compensation: an organizational adaptation perspective, The Journal of American Academy of Business 8(2): 235-241.

Clean Energy States Alliance Press Release, January 29, 2004. Clean Energy Group [online], [cited 6 November 2013]. Available from Internet: http://www.greenenergyohio.org/page. cfm?pageId $=498$

Cordeiro, J. J.; Sarkis, J. 2008. Does explicit contracting effectively link CEO compensation to environmental performance?, Business Strategy and the Environment 17: 304-317.

http://dx.doi.org/10.1002/bse.621

Core, J.; Guay, W.; Larcker, D. 2003. Executive compensation and incentives: a survey, Federal Reserve Bank of New York Economic Policy Review 9(1): 27-50.

Crawford, A. J.; Ezzell, J. R.; Miles, J. A. 1995. Bank CEO pay-performance relations and the effects of deregulation, The Journal of Business 68(2): 231-256. http://dx.doi.org/10.1086/296662 Cullen, J. B. 2002. Multinational management: a strategic approach. $2^{\text {nd }}$ ed. Ohio: South Western.

Davis, G. F. 2005. New directions in corporate governance, Annual Review of Sociology 31: 143-162. http://dx.doi.org/10.1146/annurev.soc.31.041304.122249

De Giovanni, P. 2012. Do internal and external environmental management contribute to the triple bottom line?, International Journal of Operations \& Production Management (32)3: 265290. http://dx.doi.org/10.1108/01443571211212574

Delmas, M.; Toffel, M. W. 2004. Stakeholders and environmental management practices: an institutional framework, Business Strategy and Environment 13(4): 209-222.

http://dx.doi.org/10.1002/bse.409

Delmas, M. A.; Toffel, M. W. 2008. Organizational responses to environmental demands: opening the black box, Strategic Management Journal 29: 1027-1055. http://dx.doi.org/10.1002/smj.701

DiMaggio, P. J.; Powell, W. W. 1983. The iron cage revisited: institutional isomorphism and collective rationality in organizational fields, American Sociological Review 48(2): 147-160. http://dx.doi.org/10.2307/2095101

Eisenhardt, M. K. 1989. Agency theory: an assessment and review, Academy of Management Review 14(1): 57-74.

Erdil, E.; Yetkiner, I. H. 2001. A comparative analysis of inter-industry wage differentials: industrialized versus developing countries, Applied Economics 33: 1639-1648.

http://dx.doi.org/10.1080/00036840010013608

Essen, M.; Heugens, P. P. M. A. R.; Otten, J. A.; Oosterhout, H. 2012. An institution-based view of executive compensation: a multilevel meta-analytic test, Journal of International Business Studies 43: 396-423. http://dx.doi.org/10.1057/jibs.2012.6

Gallarotti, G. M. 1995. It pays to be green: the managerial incentive structure and environmentally sound strategies, Columbia Journal of World Business 30(4): 38-58.

http://dx.doi.org/10.1016/0022-5428(95)90004-7

Gaver, J. J.; Gaver, K. M. 1993. Additional evidence on the association between the investment opportunity set and corporate financing, dividend and compensation policies, Journal of Accounting and Economics 16: 125-60. http://dx.doi.org/10.1016/0165-4101(93)90007-3

Gomez-Mejia, L. R., Balkin, D. B. 1992. Compensation, organizational strategy, and firm performance. Cincinnati, OH: South-Western. 
Green, K.; Morton, B.; Now, S. J. 1996. Purchasing and environmental management: interactions policies and opportunities, Business Strategy and the Environment 5(3): 188-197.

http://dx.doi.org/10.1002/(SICI)1099-0836(199609)5:3<188::AID-BSE60>3.0.CO;2-P

Greve, H. R. 2003. A behavioral theory of R\&D expenditures and innovations: evidence from shipbuilding, Academy of Management Journal 46(6): 685-702. http://dx.doi.org/10.2307/30040661 Hoover's Company Records database. 2008. Hoover's Inc. Austin, TX.

Hubbard, R. G.; Palia, D. 1995. Executive pay and performance: evidence from the U.S. banking industry, Journal of Financial Economics 39(1): 105-130.

http://dx.doi.org/10.1016/0304-405X(94)00816-J

Jackson, S. E.; Renwick, D. W. S.; Jabbour, C. J. C.; Muller-Camen, M. 2011. State-of-the-art and future directions for green human resource management: introduction to the special issue, German Journal of Research in Human Resource Management 25(2): 99-116.

Jennings, P. D.; Zandbergen, P. A. 1995. Ecologically sustainable organizations: an institutional approach, The Academy of Management Review 20(4): 1015-1052.

Joskow, P. L.; Rose, N. L.; Wolfram, 1996. Political constraints on executive compensation: evidence from the electric utility industry, RAND Journal of Economics 27(1): 165-182.

King, A; Lenox, M. 2002. Exploring the locus of profitable pollution reduction, Management Science 48(2): 289-299. http://dx.doi.org/10.1287/mnsc.48.2.289.258

Kole, S. R.; Lehn, K. M. 1999. Deregulation and the adaptation of governance structure: the case of the U.S. airline industry, Journal of Financial Economics 52: 79-117.

http://dx.doi.org/10.1016/S0304-405X(99)00005-7

Krueger, A. B.; Summers, L. H. 1988. Efficiency wages and inter-industry wage structure, Econometrica 56: 259-293. http://dx.doi.org/10.2307/1911072

Kulwiec, R. A. 2002. Reverse logistics - the green approach, Journal of Material Handling Industry of America (MHOVE) 2(04): 1-16.

Lai, K.; Wong, C. W. Y. 2012. Green logistics management and performance: some empirical evidence from Chinese manufacturing exporters, Omega 40: 267-282.

http://dx.doi.org/10.1016/j.omega.2011.07.002

Lawler, E. E. 1987. What's wrong with point factor job evaluation?, Personnel 64(1): 38-44.

Lin, C.; Su, D. 2009. Does state control affect managerial incentives? Evidence from China's publicly listed firms, Journal of Business Economics and Management 10(4): 291-311.

http://dx.doi.org/10.3846/1611-1699.2009.10.291-311

Livingstone, S.; Sparks, L. 1994. The new German packaging laws: effects on firms exporting to Germany, International Journal of Physical Distribution and Logistics Management 24(7):15-25. http://dx.doi.org/10.1108/09600039410070957

Lothe, S.; Myrtveit, I. 2003. Compensation systems for green strategy implementation: parametric and non-parametric approaches, Business Strategy and the Environment 12: 191-203.

http://dx.doi.org/10.1002/bse.359

Milkovich, G. T. 1988. A strategic perspective on compensation management, Research in Personnel and Human Resource Management 6: 263-288.

Moriarty, J. 2009. How much compensation can CEOs permissibly accept?, Business Ethics Quarterly 19(2): 235-250. http://dx.doi.org/10.5840/beq200919212

Murphy, K. 1999. Executive compensation, in O. Ashenfelter, D. Card (Eds.). Handbook of labor economics 3. Amsterdam: North-Holland. http://dx.doi.org/10.1016/S1573-4463(99)30024-9

Murphy, P. R.; Poist, R. F.; Braunschwieg, C. D. 1995. Role and relevance of logistics to corporate environmentalism: an empirical assessment, International Journal of Physical Distribution and Logistics Management 25(2): 5-19. http://dx.doi.org/10.1108/09600039510083916 
Nawrocka, D. 2008. Environmental supply chain management, ISO 14001 and ROHS. How are small companies in the electronics sector managing?, Corporate Social Responsibility and Environmental Management 15(6): 349-60. http://dx.doi.org/10.1002/csr.176

Neal, D. 1993. Supervision and wages across industries, The Review of Economics and Statistics 75(3): 409-417. http://dx.doi.org/10.2307/2109454

O'Reilly III, C. A.; Main, B. G. M. 2007. Setting the CEO's pay: it's more than simple economics, Organizational Dynamics 36(1): 1-12. http://dx.doi.org/10.1016/j.orgdyn.2006.12.007

Orsato, R. J. 2006. Competitive environmental strategies: when does it pay to be green?, California Management Review 48(2): 127-143. http://dx.doi.org/10.2307/41166341

Pohlen, T. L.; Farris II, M. T. 1992. Reverse logistics in plastics recycling, International Journal of Physical Distribution and Logistics Management 22(7): 35-47.

http://dx.doi.org/10.1108/09600039210022051

Powell, W. W.; Dimaggio, P. J. 1991. The new institutionalism in organizational analysis. Chicago: University of Chicago Press.

Rehman, M. A. A.; Shirvastava, R. L. 2011. An innovative approach to evaluate green supply chain management (GSCM) drivers by using interpretive structural modeling (ISM), International Journal of Innovation and Technology Management 8(2): 315-336.

http://dx.doi.org/10.1142/S0219877011002453

Renwick, D.; Redman, T.; Maguire, S. 2008. Green HRM: a review, process model, and research agenda, University of Sheffield Working Paper [online], [cited 6 November 2013]. Available from Internet: http:/www.sheffield.ac.uk/polopoly_fs/1.120337!/file/Green-HRM.pdf

Rogers, J.; Trüb, B. 2008. Business Facilities Rankings Report 2008 [online], [cited 6 November 20]. Available from Internet: http://www.westernmassedc.com/news/2008rankingsreport_728/

Rojšek, I. 2001. From red to green: towards the environmental management in the country in transition, Journal of Business Ethics 33(1): 37-50. http://dx.doi.org/10.1023/A:1011977116496

Shapiro, S. P. 2005. Agency theory, Annual Review of Sociology 31: 263-284.

http://dx.doi.org/10.1146/annurev.soc.31.041304.122159

Sharma, S. 2000. Managerial interpretations and organizational context as predictors of corporate choice of environmental strategy, Academy of Management Journal 43(4): 681-697.

http://dx.doi.org/10.2307/1556361

Smith, C. W.; Watts, R. L. 1992. The investment opportunity set and corporate financing, dividend and compensation policies, Journal of Financial Economics December: 263-292.

http://dx.doi.org/10.1016/0304-405X(92)90029-W

Stanwick, P. A.; Stanwick, S. D. 2001. CEO compensation: does it pay to be green?, Business Strategy and the Environment 10(3): 176-182. http://dx.doi.org/10.1002/bse.284

Starik, M.; Marcus, A. A. 2000. Introduction to the special research forum on the management of organizations in the natural environment: a field emerging from multiple paths, with many challenges ahead, Academy of Management Journal 43(4): 539-546.

http://dx.doi.org/10.2307/1556354

Thaler, R. H. 1989. Anomalies, Journal of Economic Perspectives 3(2): 181-193.

http://dx.doi.org/10.1257/jep.3.2.181

Tosi, H. L.; Werner, S., Katz, J. P.; Gomez-Mejia, L. R. 2000. How much does performance matter? A meta-analysis of CEO pay studies, Journal of Management 26(2): 301-339.

http://dx.doi.org/10.1177/014920630002600207

Walls, J. L.; Hoffman, A. J. 2012. Exceptional boards: environmental experience and positive deviance from institutional norms, Journal of Organizational Behavior 34(2): 253-271.

http://dx.doi.org/10.1002/job.1813 
Walls, J. L.; Berrone, P.; Phan, P. H. 2012. Corporate governance and environmental performance: is there really a link?, Strategic Management Journal 33: 885-913.

http://dx.doi.org/10.1002/smj.1952

Wingfield, B.; Marcus, M. 2007. Americas green states [online], [cited 23 January 2014]. Available from Internet: http://www.forbes.com/2007/10/16/environment-energy-vermont-biz-beltwaycx_bw_mm_1017greenstates.html

Winsemius, P.; Guntram, U. 1992. Responding to the environmental challenge, Business Horizons 35(2): 12-20. http://dx.doi.org/10.1016/S0007-6813(05)80188-0

Wolfson, P.; Belman, D. 2004. The minimum wage: consequences for prices and quantities in low-wage labor markets, Journal of Business \& Economics 22(3): 295-311.

Yen, Y.; Yen, S. 2012. Top-management's role in adopting green purchasing standards in hightech industrial firms, Journal of Business Research 65: 951-959.

http://dx.doi.org/10.1016/j.jbusres.2011.05.002

Zee, S. M. L.; Fok, L. Y.; Harman, S. J. 2011. Exploring the relationships between organizational size and market focus and commitment to the green movement and impacts of organizational culture: a comparative study of Jamaica and the United States, International Journal of Business and Social Science 2(22): 19-34.

Zucker, L. G. 1987. Institutional theories of organization, Annual Review of Sociology 13: 443464. http://dx.doi.org/10.1146/annurev.so.13.080187.002303

A. Banu GOKTAN, Dr, is an Assistant Professor of Management at the University of North Texas at Dallas. Her current research interests are in the areas of green management practices, entrepreneurship and national culture. 